\title{
MODELING THE ENVIRONMENTAL IMPACTS OF LANDLFILING AND INCINERATION WASTE MANAGEMENT SCENARIOS WITH $\mathrm{GaBi}_{6}$ TOOL
}

\author{
O.S. Olaniyan ${ }^{1}$, S.O. Ojoawo ${ }^{2}$, R.A. Olaoye ${ }^{3}$, A.S. Akolade ${ }^{4}$, B.K. Olawoore ${ }^{5}$, E.R. Oyediran ${ }^{6}$ \\ ${ }^{I}$ Department of Civil Engineering, Ladoke Akintola University of Technology, P.M.B 4000, Ogbomoso Oyo State, \\ Nigeria \\ ${ }^{2}$ Department of Civil Engineering, Ladoke Akintola University of Technology, P.M.B 4000, Ogbomoso Oyo State, \\ Nigeria \\ ${ }^{3}$ Department of Civil Engineering, Ladoke Akintola University of Technology, P.M.B 4000, Ogbomoso Oyo State, \\ Nigeria \\ ${ }^{4}$ Department of Civil Engineering, Ladoke Akintola University of Technology, P.M.B 4000, Ogbomoso Oyo State, \\ Nigeria \\ ${ }^{5}$ Department of Civil Engineering, Ladoke Akintola University of Technology, P.M.B 4000, Ogbomoso Oyo State, \\ Nigeria \\ ${ }^{6}$ Department of Civil Engineering, Ladoke Akintola University of Technology, P.M.B 4000, Ogbomoso Oyo State, \\ Nigeria \\ soojoawo@lautech.edu.ng
}

\begin{abstract}
Improper solid wastes management poses environmental risks to both humans and plants. Landfilling and Incineration are two identified prominent means of waste disposal, and they both have residual pollution impacts on the environment. This study assessed the environmental impacts of these waste disposal methods from the waste dumps of Odo-Oba, Ogo Oluwa Local Government Area, Nigeria. Field Survey, questionnaire interviews, and measurement of trace gases emitted from the dumps were carried out. Wastes were sorted, weighed and characterized. Two Scenarios of Landfilling and Incineration were formulated and the field data were modeled with $\mathrm{GaBi}_{6}$ software to determine the environmental impact of the waste.

Findings show that the present method of waste management in Odo-Oba area is inadequate as there is no landfill and open burning of indiscriminate dumps is in practice. The waste generated is majorly of agricultural products of about $43 \%$ composition. Others in decreasing magnitude include nylon, metals, paper, plastic, textiles, ashes and demolition respectively. The per capita waste generation per day within the agricultural market is $0.92 \mathrm{~kg}$ per day while that of the selected residential houses is $0.31 \mathrm{~kg}$ per day. Wastes are usually burnt on daily basis, leading to emission of certain trace gases of which methane is of the highest concentration of 619 ppm. For landfilling model, paper contributes the highest in Global Warming Potential and Eutrophication Potential whereas biodegradable materials and plastic materials dominate in Acidification Potential and Ozone Depletion Potential respectively. Glass and metal has the least noticeable impacts. From incineration model, plastic materials contribute the highest environmental impact in Acidification Potential, Global Warming Potential and Eutrophication Potential while metals have the least influence in all cases, aside the Ozone Depletion Potential having glass materials. The landfill model thus poses lesser environmental threat and its sanitary type is therefore recommended for use in the study area.
\end{abstract}

Keywords: Environmental impact indices, GaBi ${ }_{6}$ tool, Life Cycle Assessment, Landfilling, Incineration

\section{INTRODUCTION}

Waste is a material that is no longer useful and to be disposed of. Domestic wastes include those from domestic premises, caravan sites, residential homes, educational establishments, and nursing homes and hospitals which can be organic or non-organic. Solid waste is the unwanted or useless solid materials generated from combined residential, industrial and commercial activities in a given area. It may be categorized according to its contents as organic material, glass, metal, plastic paper etc) or according to hazard potential as toxic, non-toxin, flammable, radioactive, infectious (Agbede, 1994; IHSE,1999; Sridhar, 2000; Ojoawo et al. 2011). Solid waste management (SWM) is about all activities (handling, collection, transportation, storage, processing, treatment and disposal) that seek to minimize health and environmental hazards capable of arising from solid wastes. The objective of SWM is basically the efficient use of resources in the process of managing waste materials (Clairvair, 2006). The management of waste is presently a matter of international concern. The volume of waste does not actually 
constitute the problem but the ability or inability of governments, individuals and waste disposal firms to keep up with the task of managing the waste and environment. SWM is one of the most difficult environmental sanitation challenges facing the developing countries perhaps due to lack of proper legislation and enforcements.

In the recent time, waste management through Life Cycle Assessment (LCA) is becoming more popular. LCA has been defined as an objective process to evaluate the environmental burdens associated with a product, process or activity, by identifying and quantifying energy and materials used and waste released to the environment while evaluating and implementing opportunities to allow environmental improvements Barton, et al. (1996). The LCA is currently being used in several countries to evaluate treatment option for specific waste fractions (Finnveden, 1999; Ozeler, et al. 2006; Obersteiner, et al. 2007; Boer, et al. 2007; Winkler and Bilitewski 2007; Borghi, et al. 2007). Environmental LCA is a system analysis tools. It was developed rapidly during the 1990s and has reached a certain level of harmonization and standardization. The LCA of product commence with extracting of raw materials through the process of logging, mining etc and ends with final disposal of products. The life cycle of waste on the other hand, starts when a material is discarded into the waste stream and ends when the material has either been converted into a resource (such as recycled materials or recovered energy) or, when it is finally disposed.

Application of GaBi LCA modelling technique solves the problem of imprecision involved in solid waste decision making (Ojoawo et al, 2014). GaBi software is that which support every stage of an LCA, from data collection and organization to presentation of result and stakeholder engagement.GaBi automatically tracks all material, energy, and emissions flows, as well as defined monetary values, working time and social issues, giving instant performance accounting in dozens of environmental impact categories. $\mathrm{GaBi}$ allows rapid modeling even of complex processes and different production options.

The GaBi software is complemented by the most comprehensive, up-to-date Life Cycle Inventory database available. For this study, the computer program $\mathrm{GaBi}_{6}$ has been utilized. $\mathrm{GaBi}$ software has been developed in accordance with the ISO 14040 and ISO 14044 standards and allows for managing and storing the necessary data, as well as performing the calculations and required sensitivity tests.

Two major scenarios in common use for LCA processes are landfilling and incineration. For a semi-urban area like Ogbomoso South Local Government Area of Nigeria, it has been found that landfilling scenario poses lesser burden on the environment as compared to incineration (Ojoawo and Gbadamosi, 2013).

The present research aims at modeling the environmental impacts of both the landfiling and incineration scenarios in a rural area. Odo- Oba, the study area is situated in OgoOluwa Local Government Area (LGA) of Oyo State, Nigeria. Ogo-Oluwa LGA is one of 5 in Ogbomoso. The name Odo-oba was derived from the steam that flows through the area. The steam serve as boundary between Oyo state and Osun state. The Community has between 120-150 residential houses and a popular agricultural market known as "Odo-oba market" which is located along OgbomosoOyo road. Refuse is equally being generated from commercial shops, schools, and related institutions in the area. The central objective is to assess the environmental impacts of wastes in the study area through $\mathrm{GaBi}_{6}$ modeling tool. The choice of Odo-Oba Community in Ogo-Oluwa Local Government areas is primarily due to the fact that wastes being generated could either be landfilled or incinerated after proper sorting.

\section{METHODOLOGY}

\subsection{Reconnaissance Survey and Waste Collection}

The first-hand information of how the waste is being managed and the noticeable deficiencies in the management system was sought. Personal Observation and Interview were the two methods of Data Collection employed in this study. In the process, existing conditions of how each refuse dump is being managed was observed. Personal interview with the residents was conducted on how their refuse is being stored, collected, transported, managed and the various agencies involved in its management. For waste collection, thirty (30) shops, ten (10) residential houses, were selected for the exercise. Special nylons were provided for each of them for the collection twice a week over a period of 2 months.

\subsection{Waste Sorting}

This is the process of separating the different composition of the waste generated by the marked locations. It involves the separation of wastes into its components like biodegradables, plastics, metals, textiles, ashes, and nylons.

\subsection{Gas Measurement with Portable Detectors}

Three (3) gases: $\mathrm{CO}_{2}, \mathrm{CH}_{4}$ and $\mathrm{SO}_{2}$ were monitored at the selected dumpsite behind the Odo-oba market with ToxiRAE portable gas detectors. The ToxiRAE is capable of detecting a broad range of gases through its intelligent interchangeable sensors. The temperature of each sampling station was noted at the time of gas monitoring. Replica measurements were made before and after burning of wastes.

\subsection{Modeling of Parameters with Software $\left(\mathrm{GaBi}_{6}\right)$}

The 2 formulated scenarios for this study are landfill and incineration. The environmental impact indices are Acidification Potential (AP), Ozone Depletion Potential (ODP), Global Warming Potential (GWP) and Eutrophication Potential (EP). Modeling of parameters of the study includes data compilation, quantification and 
analysis based on International Reference Life Cycle Data System (ILCD) recommendations.

\subsubsection{Landfill Model}

This includes Collection (C), Sorting (S), Transportation (T) and Landfilling (L). LCA modeling is achieved using plan, process and flow. The plan represent the system boundary of the LCA, process represent real life activities in the life cycle of the product being analysed (e.g. transportation), while flow represent the materials and energy in the system. The flow in the model follows the direction of the arrow as shown in Figure 1.

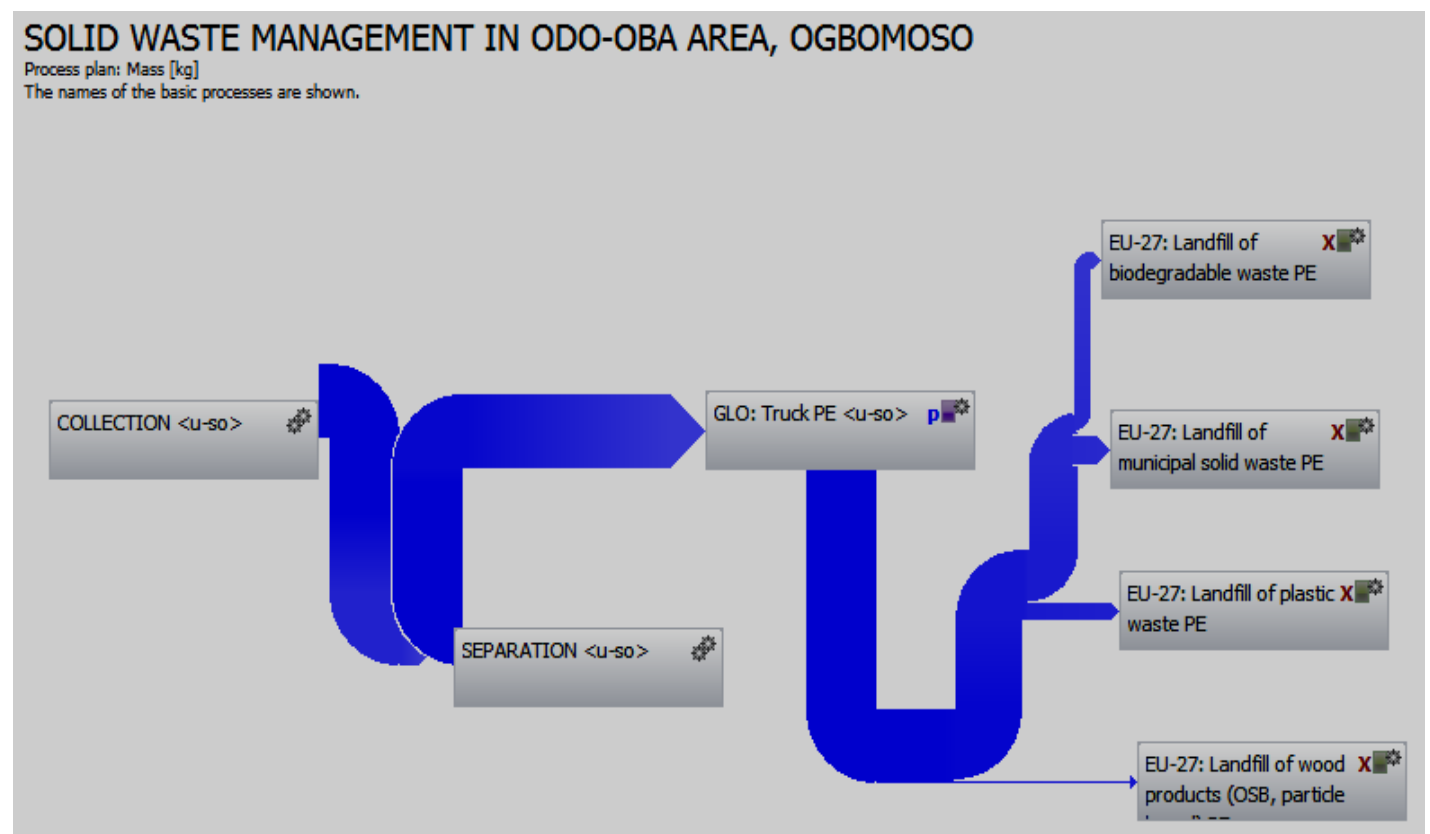

Fig 1: Landfill Model of waste management developed using $\mathrm{GaBi}_{6}$ software.

\subsubsection{Incineration Model}

In the incineration model, Collection (C); Sorting (S); Transportation (T); and Incineration (I) were considered.
The flow within the system is in the direction of the arrow. Incineration model of waste management was developed using $\mathrm{GaBi}_{6}$ software as shown in Figure 2.



Fig 2: Incineration Model of waste management developed using $\mathrm{GaBi}_{6}$ software. 


\section{RESULTS AND DISCUSSIONS}

\subsection{Analysis of Questionnaire and the Collected}

\section{Wastes}

From the administered questionnaire data obtained in the course of carrying out this project shows that wastes are being disposed indiscriminately in the study area. All the thirty (30) residential houses and 10 shops from where wastes were collected responded promptly. It is found that there is no organized landfill in the area, wastes are being dumped indiscriminately at the river banks and vacant landed properties. Most respondents revealed that there is an irregular pattern noted in the waste collection system of the LGA. About $80 \%$ confirmed that open burning of these wastes is embarked upon as an alternative mean. After sorting and weighing, the average $\%$ composition of wastes generated from the study is as shown on Table 1.

Table 1: Average percent composition of waste generated in the study area

\begin{tabular}{|l|l|}
\hline Waste Type & \% Composition \\
\hline Agricultural/biodegradables & 42.2 \\
\hline Plastic & 9.3 \\
\hline Metals & 10.1 \\
\hline Textiles & 6.4 \\
\hline Nylon & 19.4 \\
Paper & 9.6 \\
\hline Ashes and demolition & 3.0 \\
\hline
\end{tabular}

The result shows the dominancy of agricultural and biodegradable wastes with about $2 / 5^{\text {th }}$ of entire generated wastes in the study area. This may be due to the fact that the major occupation of Odo-Oba residents is farming while a few of them are engaged in trading of farm produce, food provisions and related items. The nearly $20 \%$ nylons and $10 \%$ paper might have come from the packaging of these agricultural items while being sold. Metal scraps and worn textiles found on dumpsites have about 10 and 7 percentages respectively. Ashes and demolition items constitute about $3 \%$ of the total wastes. This observed pattern is similar to those earlier reported in rural areas of Ogbomosoland respectively for putrescibles, metals, textile and ashes as 68.4, 7.2, 4.7, and 1.9 (Ojoawo et al. 2011).

\subsection{Waste Generation Per Capita}

The per capita waste generated per day is estimated from the measured weight of waste generated by a marked location (in $\mathrm{kg}$ ) divided by the approximate population of the residents there in the given day. The per capita waste generation within the agricultural market in Odo-Oba Area is found as $0.92 \mathrm{~kg} /$ day while that of other selected residential areas is $0.31 \mathrm{~kg} / \mathrm{day}$.

\subsection{Gas Emission from the Selected Dumpsite}

Table 2 shows the concentration of gases emitted from the selected dumpsite both prior to and after burning of the wastes. The result shows that carbondioxide gas $\mathrm{CO}_{2}$ marginally increased by $4 \mathrm{ppm}$ after burning. $\mathrm{CH}_{4}$ was barely undetected before burning but after burning it has increased to $619 \mathrm{ppm}$ at a temperature of $46.3{ }^{\circ} \mathrm{C}$. $\mathrm{SO}_{2}$ was however not detected throughout the process.

Table 2: Result of Gas emission from the selected waste dumpsite

\begin{tabular}{|l|l|l|l|l|}
\hline Gases & Temperature ${ }^{0} \mathrm{C}$ & $\begin{array}{l}\text { Before burning (in } \\
\text { ppm) }\end{array}$ & Temperature ${ }^{0} \mathrm{C}$ & $\begin{array}{l}\text { After burning } \\
\text { (in ppm })\end{array}$ \\
\hline $\mathrm{CO}_{2}$ & 44.1 & 298 & 46.3 & 302 \\
\hline & 45.7 & 400 & 47.1 & 400 \\
\hline $\mathrm{CH}_{4}$ & 02 & 46.3 & 502 \\
\hline $\mathrm{SO}_{2}$ & 44.1 & 0 & 47.0 & 619 \\
\hline & 45.7 & 0 & 46.3 & 0 \\
\hline
\end{tabular}

\subsection{Modeling of Field Measurements with GaBi6} Tool

\subsubsection{Life Cycle Impact Assessment for Landfill}

\section{Model}

The results of the International reference Life Cycle Data System (ILCD) recommendation of the two models; landfill and incineration are presented in Figures 3 to 6 respectively. From the measured environmental impact indices, using ILCD recommendation in $\boldsymbol{G} \boldsymbol{a B} \boldsymbol{i}_{\boldsymbol{\sigma}}$ database, paper materials contribute the highest in GWP and EP whereas biodegradable materials and plastic materials dominate in AP and ODP respectively. Glass and metal has the least noticeable impacts according to ILCD recommendations on landfilling. Since landfilling is unsuitable to metal and glass disposal the trends observed is justified. 


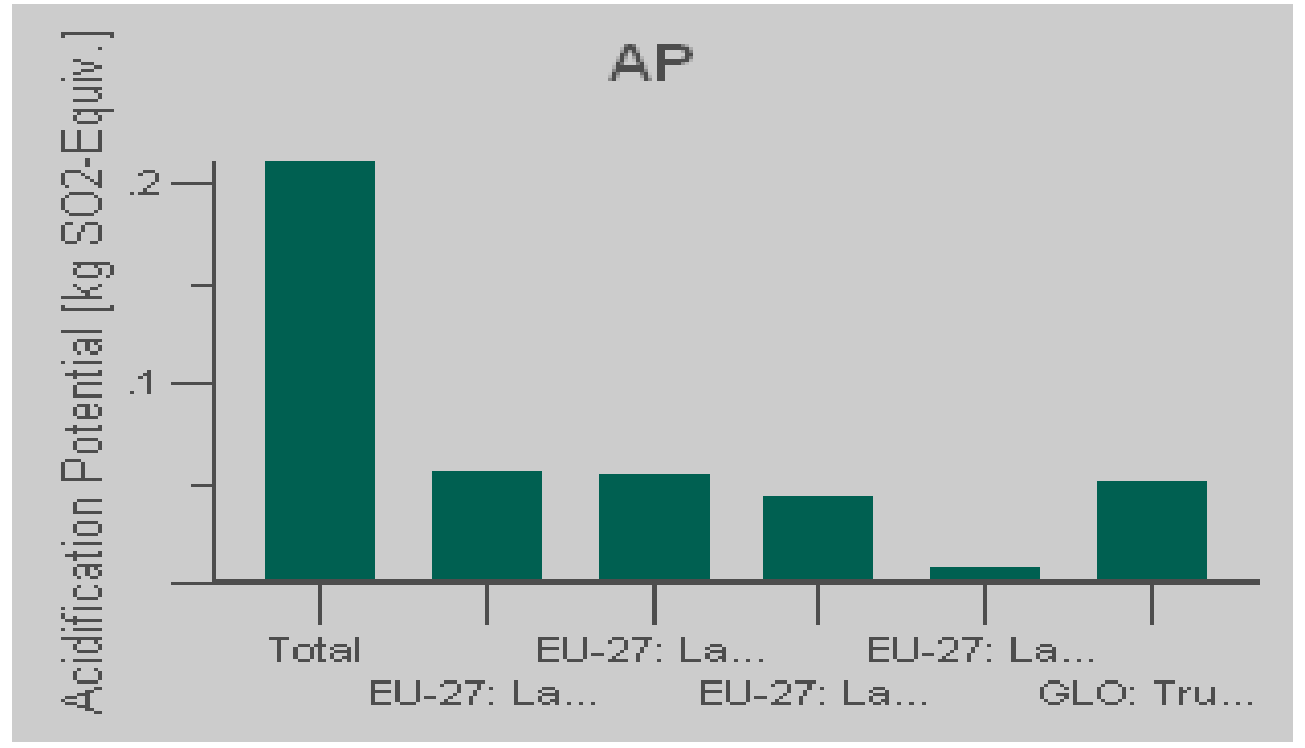

Fig 3: AP through Life Cycle Impact Assessment for Landfilling

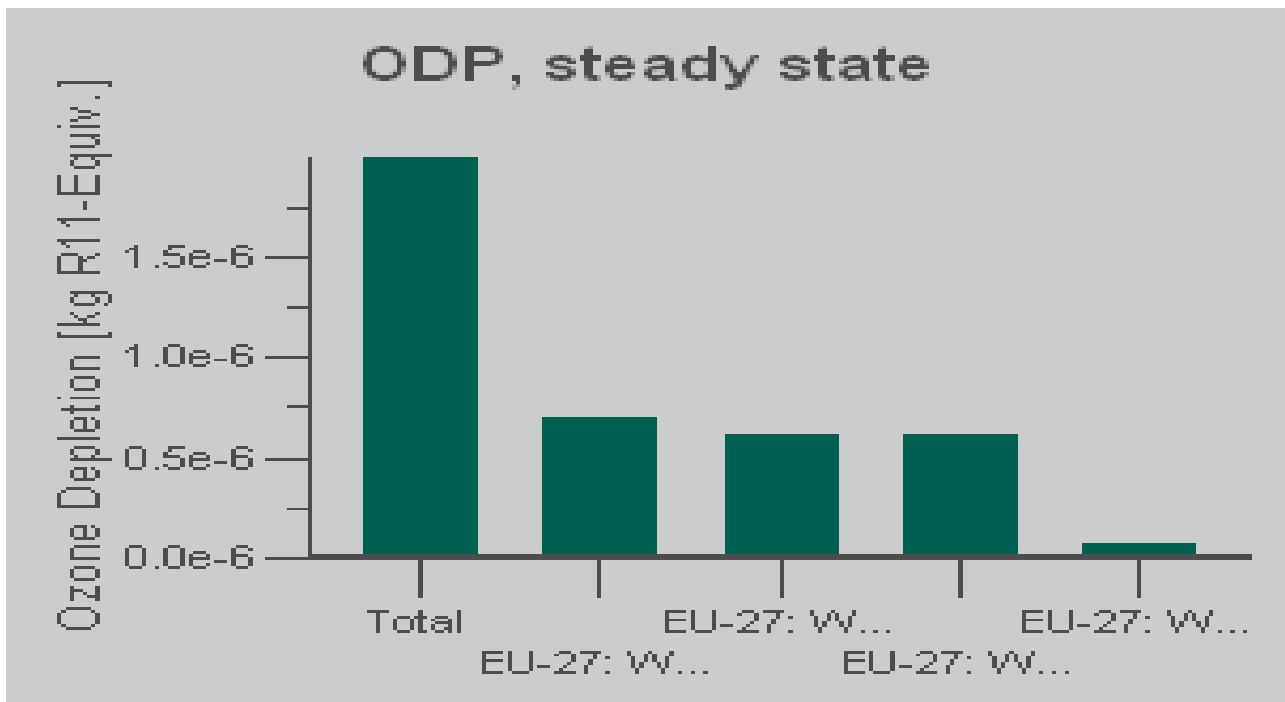

Fig 4: ODP through Life Cycle Impact Assessment for Landfilling

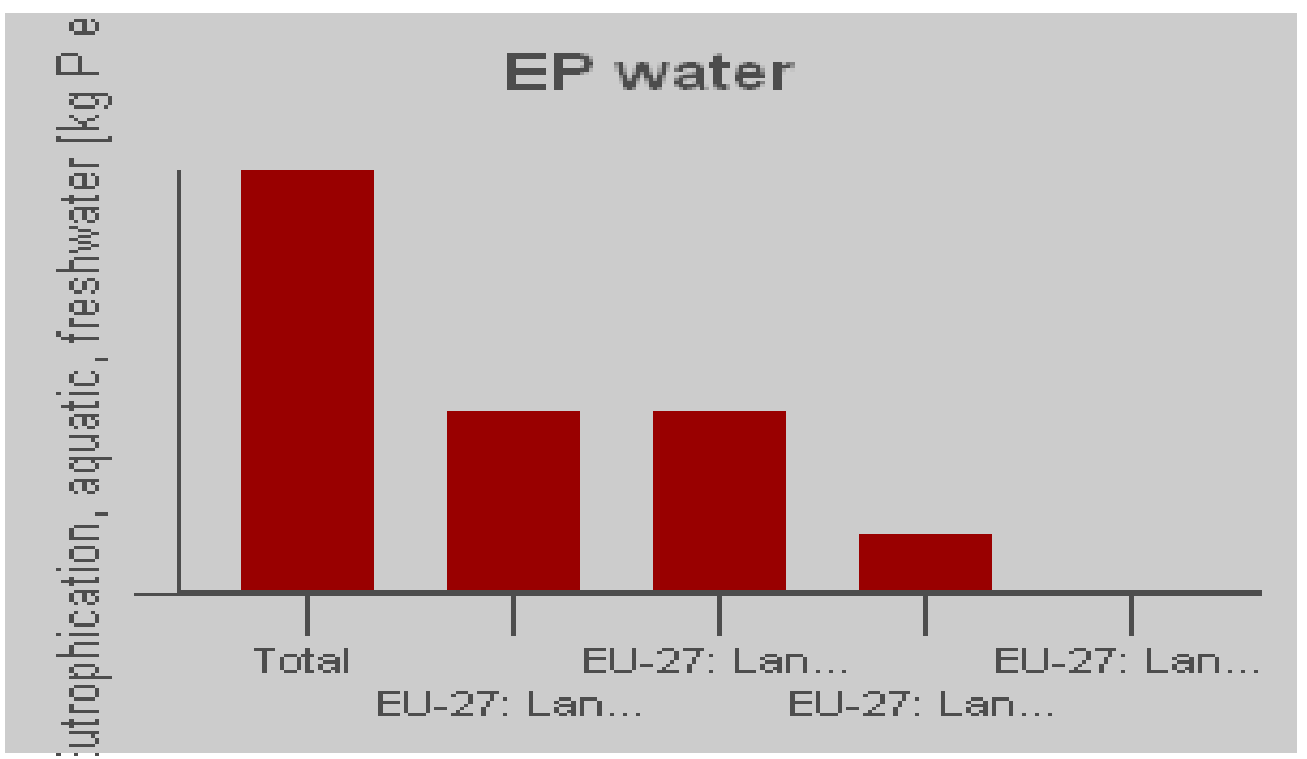

Fig 5: EP through Life Cycle Impact Assessment for Landfilling 


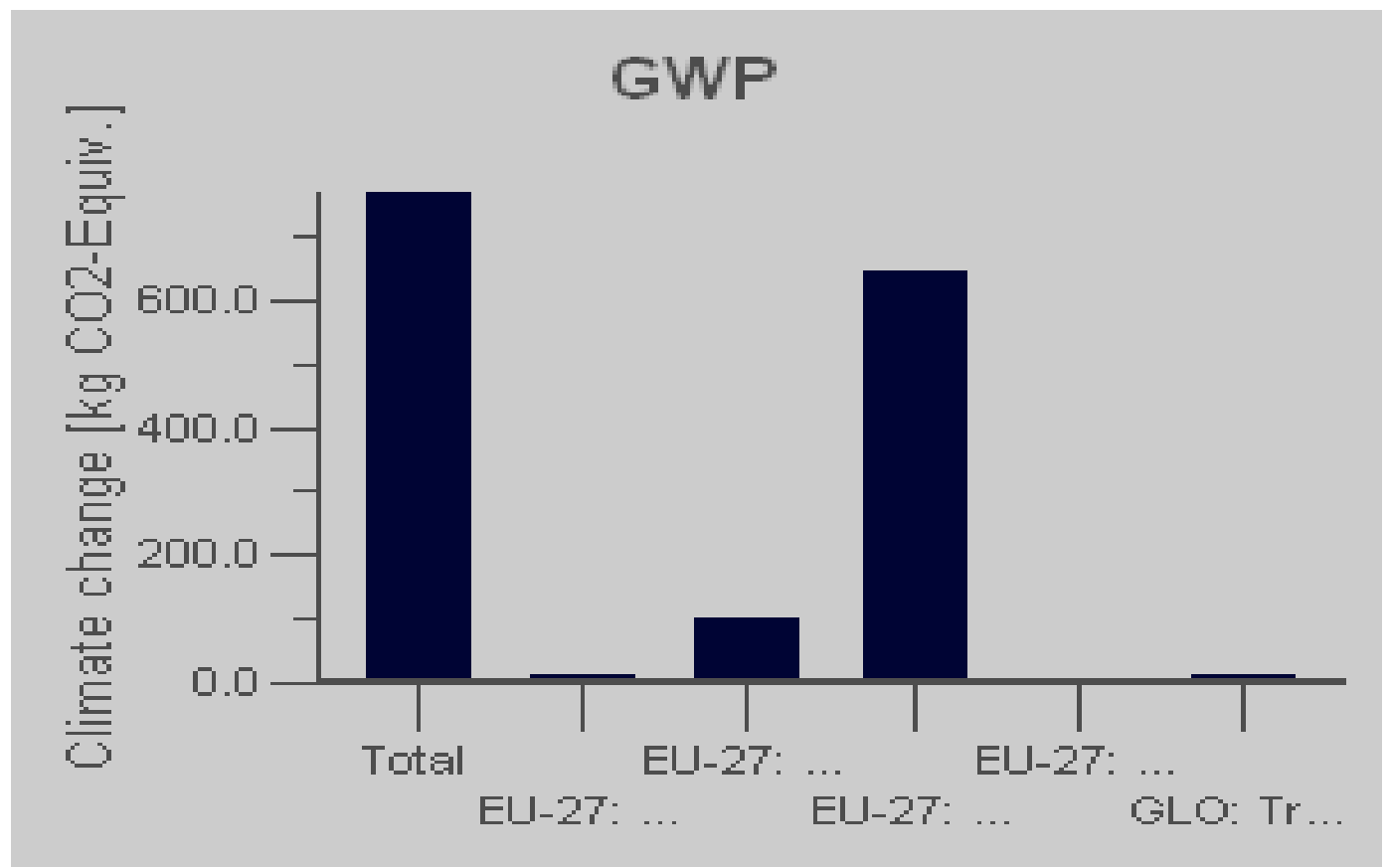

Fig 6: GWP through Life Cycle Impact Assessment for Landfilling

\subsubsection{Life Cycle Impact Assessment for Incineration}

\section{Model}

From the impact category indices of incineration model, plastic materials contribute the highest environmental impact in AP, GWP and EP while metals have the least influence in all cases aside ODP having glass materials.

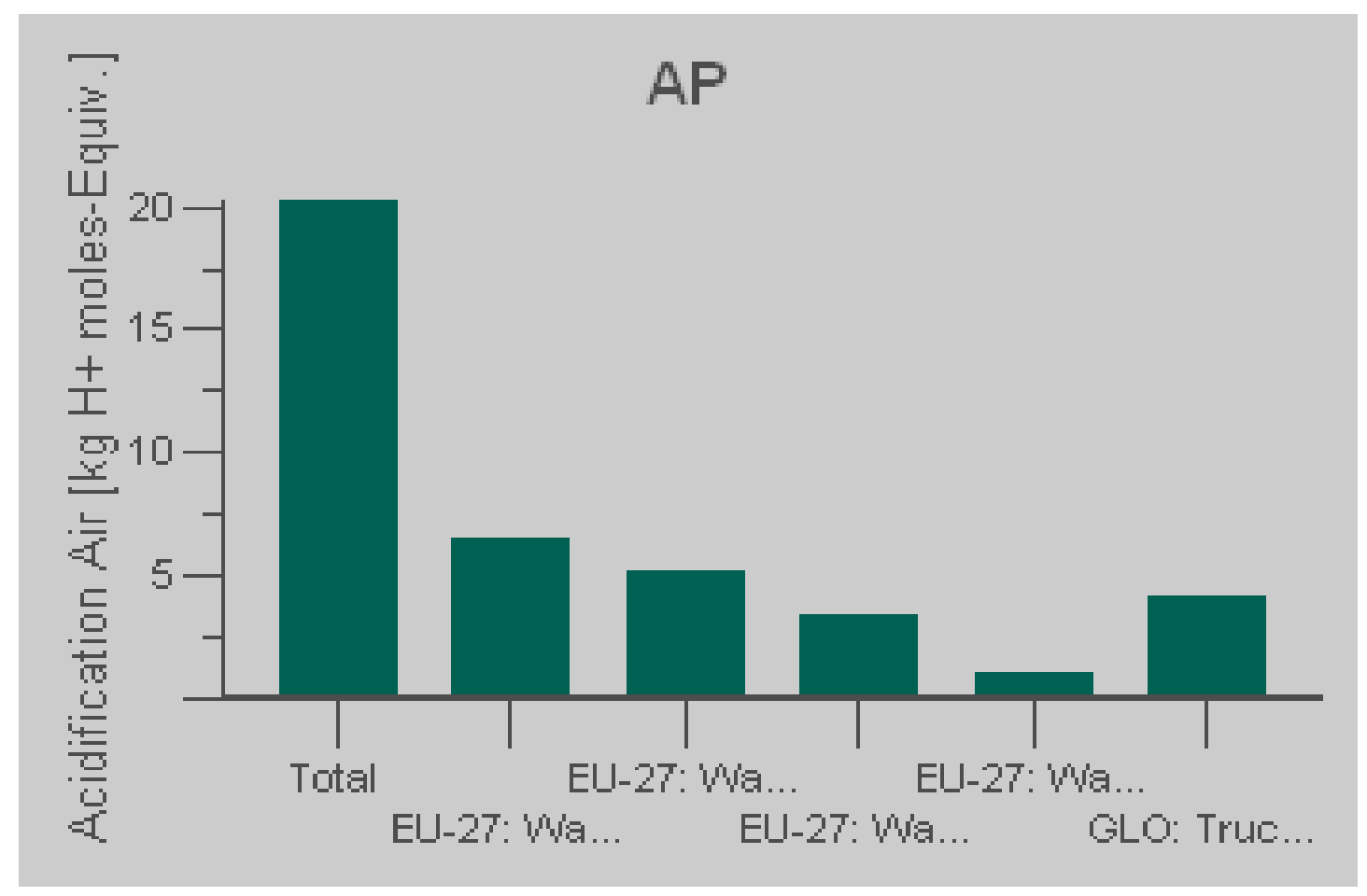

Fig 7: AP through Life Cycle Impact Assessment for Incineration 


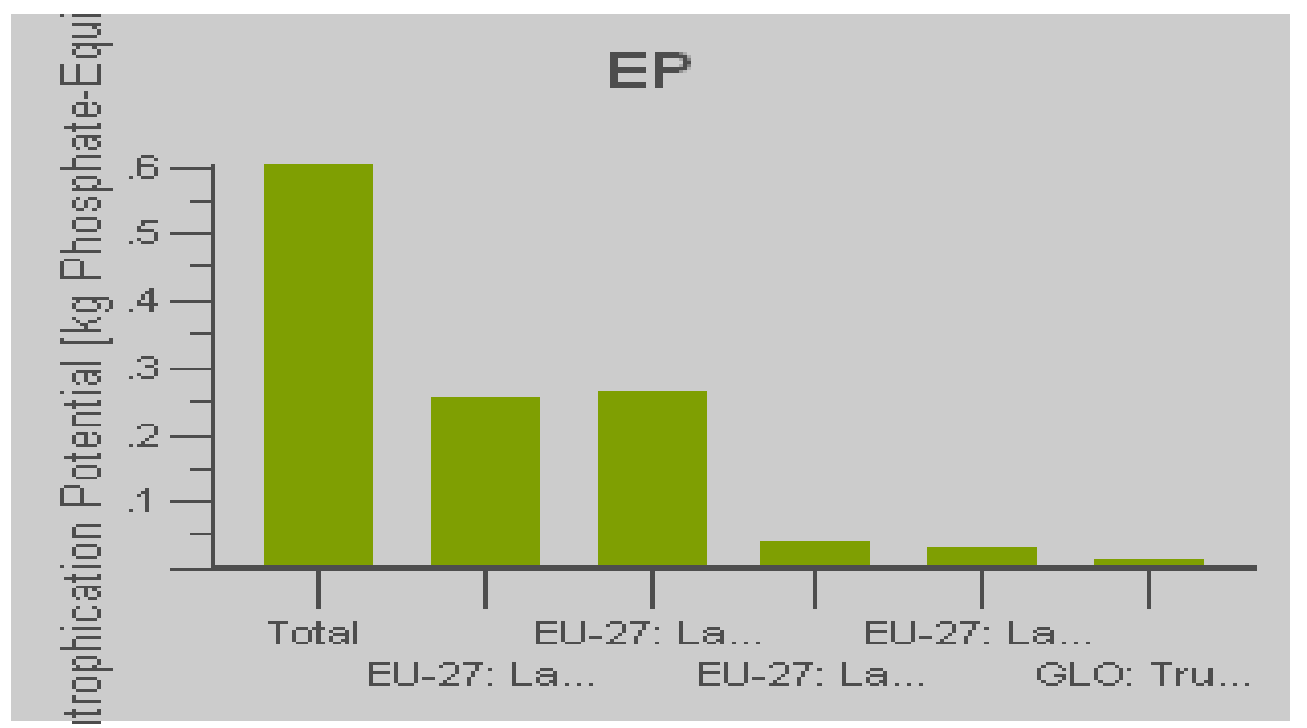

Fig 8: EP through Life Cycle Impact Assessment for Incineration

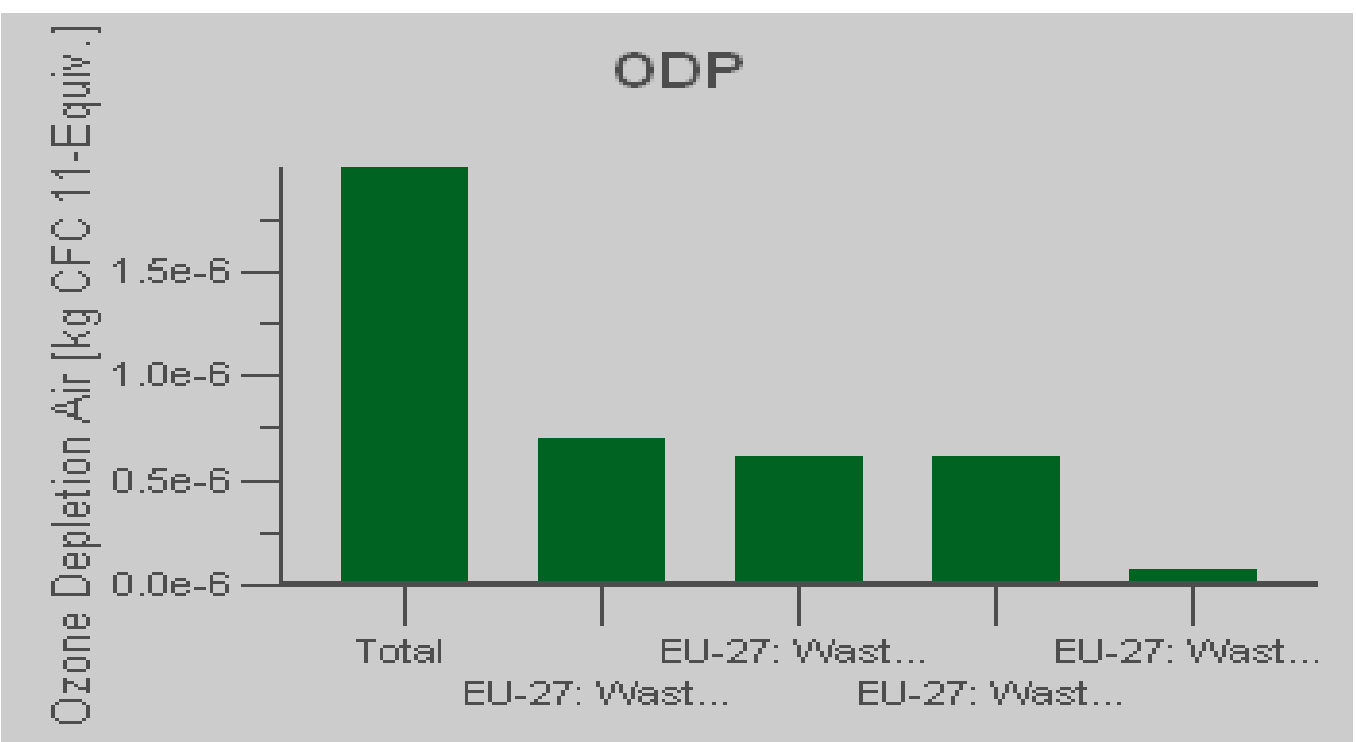

Fig 9: ODP through Life Cycle Impact Assessment for Incineration

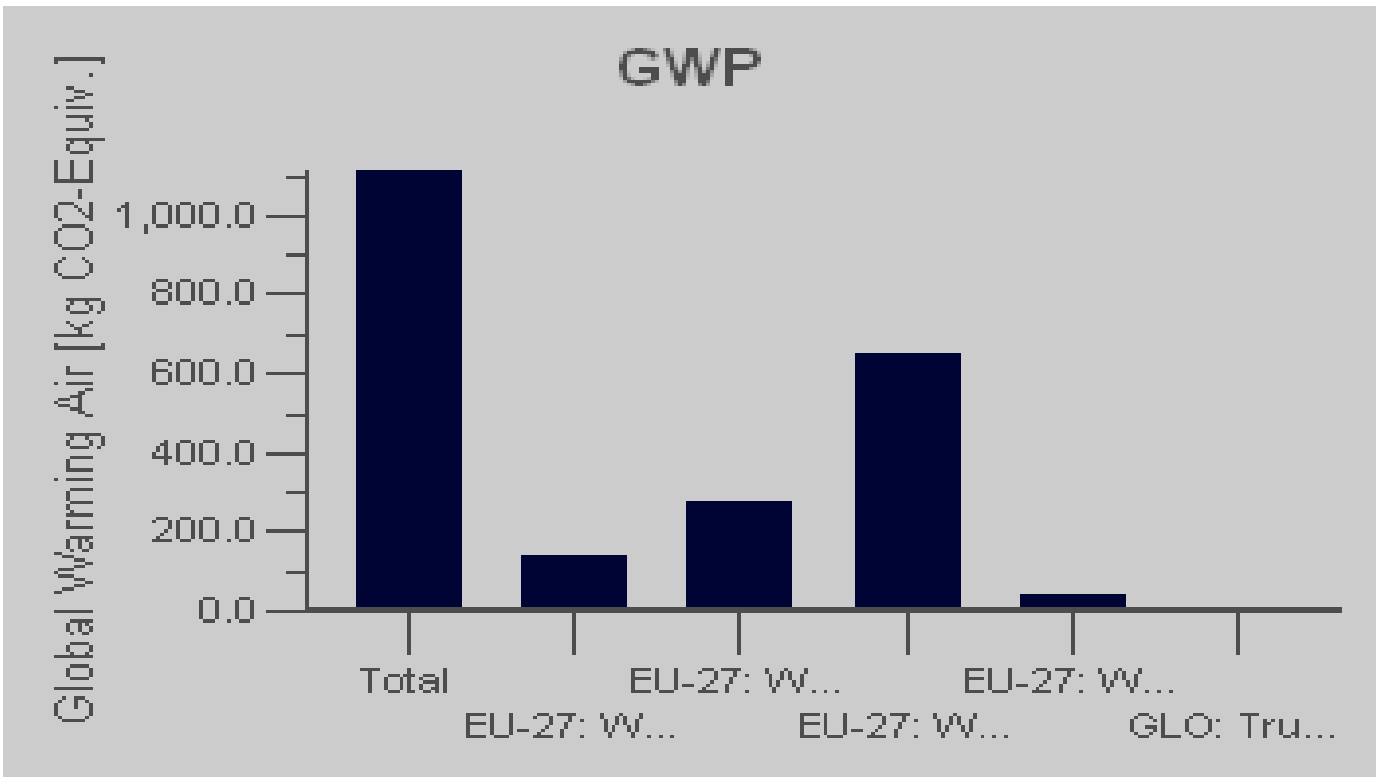

Fig 10: GWP through Life Cycle Impact Assessment for Incineration 
From all the LCIA Figures 3 to 10 it is clearly depicted that Agricultural wastes constitute highest percentage in the study area, and the trends observed in other components are in line with the waste composition in Table 1.

\section{CONCLUSION AND RECOMMENDATIONS}

This study concludes that the present method of waste management in Odo-Oba area is inadequate as there is no landfill and open burning of indiscriminate dumps is in practice. There is no regular collection, transportation and for proper disposal system for wastes being generated in the area. The waste generated in the study area is majorly of agricultural products. Others in decreasing magnitude include nylon, metals, paper, plastic, textiles, ashes and demolition respectively. The per capita waste generation per day within the agricultural market is $0.92 \mathrm{~kg}$ per day while that of the selected residential houses is $0.31 \mathrm{~kg}$ per day. Wastes are usually burnt on daily basis, this leads to emission of certain trace gases of which methane is of the highest concentration of $619 \mathrm{ppm}$.

For environmental impact indices through landfilling, paper contributes the highest in Global Warming Potential and Eutrophication Potential whereas biodegradable materials and plastic materials dominate in Acidification Potential and Ozone Depletion Potential respectively. Glass and metal has the least noticeable impacts. From the impact category indices of incineration model, plastic materials contribute the highest environmental impact in Acidification Potential, Global Warming Potential and Eutrophication Potential while metals have the least influence in all cases, aside the Ozone Depletion Potential having glass materials.

The landfill model thus poses lesser environmental threat and its sanitary type is therefore recommended for use in the study area.

\section{REFERENCES}

[1] Agbede, O.A (1994) Groundwater Pollution Levels in Nigeria, Proceedings of 20th WEDC Conference, Sri Lanka, Colombo, p. 3.

[2] Aigbokan A. (2007): Industrial pollution in Lagos, Ogun and Oyo States. Unpublished Term paper Presented at University of Lagos.

[3] Barton, J.R, Dalley, D and Patel, V.S (1996) "Life Cycle Assessment for Waste Management" Waste Management, Vol. 16, No. 1-3, 1996, pp. 35-50.

[4] Boer, J., Boer, E., Jager, J. (2007) LCA-IWM: A decision support tool for sustainability assessment of waste management systems. Waste Management 27, 1032-1045.

[5] Borghi, A., Binaghi, L., Borghi, M.G.M. (2007) The application of the environmental product declaration to waste disposal in a sanitary landfill. International Journal of LCA 12 (1), 40-49.

[6] Clairvair O. Squires (October 2006), Public participation in Solid Waste management in Small Island Developing states. Caribbean Development Bank (COB).
[7] Finnveden, G. (1999) Methodological aspects of life cycle assessment of integrated solid waste management systems. Resources, Conservation and Recycling 26, 173-177.

[8] IHSE (1999) Biomedical Waste Management in Ibadan, Nigeria," A Biomedical Waste Profile on Ibadan, p.23.

[9] Moronkola, O.A and Okanlawon, F.A. (2003). Fundamental of Public and Community Health Education. Ibadan: Royal people (Nig) Ltd.

[10] Obersteiner, G., Binner, E., Mostbauer, P., Salhofer, S. (2007) Landfill modelling in LCA - a contribution based on empirical data. Waste Management 27, S58-S74.

[11] Ojoawo, S.O, Agbede, O.A and Sangodoyin, A.Y (2011) On the physical composition of solid wastes in selected dumpsites of Ogbomosoland, SouthWestern Nigeria. Journal of Water Resource and Protection, U.S.A, 3 (9): 661-666, DOI: 10.4236/jwarp. 2011.39076.

[12] Ojoawo, S.O and Gbadamosi, A.A (2013) Application of TRACI and CML modeling tools in Life Cycle Impact Assessment of municipal wastes. Journal of Environmental Protection, U.S.A, 4 (1): 602 - 617. Doi:10.4236/jep.2013.46070.

[13] Ojoawo, S.O, Bosu, J.S and Oyekanmi, O.A (2014) Characterization of environmental impact indices of solid wastes in Surulere Local Government Area, Nigeria with GaBi5 LCA modeling technique. International Journal of Modern Engineering Research, India. 4(9): 41-49.

[14] Ozeler, D., Yetis, U., Demirer, G.N. (2006) Life cycle assessment of municipal solid waste management methods: Ankara case study. Environment International 32, 405-411.

[15] Sharholy, M., Ahmad, K., Mahmood, G., Trivedi, R.C., (2008). Municipal solid waste Management in Indian cities - A review. Waste Management 28 (2): 459- 467.

[16] Shridhar, M.K.C (2000) Nature of solid wastes and their Management, A Paper Presented at a one Day Seminar Organized by NINNAFEH, Ibadan, p. 2.

[17] UNDP (United Nations Development Programme). 1997. Survey of Mayors: Major Urban Problems. (United Nations Development Programme), Washington, DC.

[18] Winkler, J., Bilitewski, B. (2007) Comparative evaluation of life cycle assessment models for solid wastes management. Waste Management 27, 10211031. 